\title{
A new Tenthredo species from Chopta, India (Hymenoptera: Tenthredinidae)
}

\author{
AtTILA Haris ${ }^{1} \&$ Malkiat S. SAINI ${ }^{2}$
}

${ }^{1}$ H-1076 Budapest, Garay utca 19 2/20, Hungary, e-mail: attilaharis@yahoo.com

2Department of Zoology Punjabi University, 147002 Patiala, India, e-mail: saini20@hotmail.com

Haris, A. \& SAIni, M. S.: A New Tenthredo species from Chopta, India (Hymenoptera: Tenthredinidae).

Asbtract: Tenthredo (Tenthredella) indonitidula spec. nov. is described from Chopta, India and compared to Tenthredo yinae Wei, 1999, Tenthredo (Tenthredella) atra Linné, 1758, Tenthredo dorsivittata (Cameron, 1902) and Tenthredo micropunctata Saini and Vasu, 2001.

Keywords: Hymenoptera, Symphyta, Tenthredinidae, Tenthredininae, Tenthredo, India, Chopta, new species

\section{Introduction}

The present paper is the second part of our previous publication titled Tenthredo (Linné, 1758) species from Chopta, India (Hymenoptera: Symphyta: Tenthredinidae) (HARIS \& SAINI, 2018). The material, similarly to the previous one, was collected by Dr. Malkiat S. Saini in Chopta, Uttarakhand state of India and after preselection and first identification was sent to Attila Haris for confirmation and analysis.

\section{Material and methods}

The material consists of 9 specimens of 8 species, all of them belong to genus Tenthredo Linné, 1758. As a result of the identification, 8 species were identified, one of them is proved to be new for science.

For identification the comprehensive works of MALAISE (1945) and SAINI (2007) were consulted compared with high number of subrecently published papers mainly from Chinese, Slovak and Hungarian authors (WEI \& Nie 1998, 2002; WeI, Wen \& Deng 1999, Wei \& Zhong 2002; Nie \& Wei 1998; Haris \& Roller 1998 and 2007 and many others, due to the extremely high number of papers, we could not list all of them, only the most relevants for our present study). For the subgeneric classification we applied the mostly accepted system of Zhelochovtsev (ZHELOCHOVTSEV 1988).

Holotype is deposited at ZSI (Zoological Survey of India) Solan (H.P).

Both authors are author of the new species: ie. Haris and Saini. 


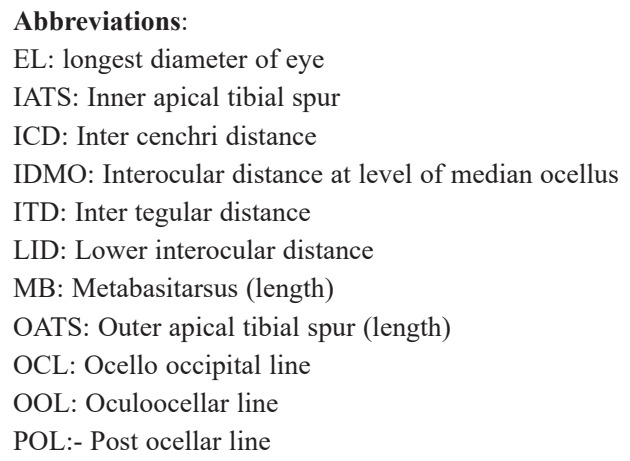

\section{Description of the new species}

Tenthredo (Tenthredella) indonitidula spec. nov. (Figs. 1 and 2)

Holotype: Female. India: Chopta, 23. 06. 2015.

Body black; rusty reddish brown: entire mandible, anterior femur, middle femur except black basal fifth, hind femur except black basal third. Cenchri brownish white. Wings hyaline, stigma and venation dark brownish black.

Head including temples and inner ocular area densely, deeply, very uniformly and minutely punctured, shiny. Shiny spaces between punctures about $1.5 \mathrm{x}$ diameter of a puncture. Vertex very densely, minutely and deeply punctured, hardly shiny, interspaces between punctures about $0.5 \times$ diameter of a puncture. Ocellar area densely, deeply and moderately roughly punctured with moderately large punctures, hardly shiny. Head with short dense brown pubescence, about half as long as diameter of anterior ocellus. Mesonotum bold. Pronotum with brown pubescence $0.7-1.0 \mathrm{x}$ diameter of anterior ocellus.

Supraantennal tubercles long and strong, deeply separated from the frontal area. Postoccipital carina complete although week but clear on vertex. Head behind eyes strongly contracted.

Ratios of antennal segments: $13: 9: 44: 36: 28: 20: 17: 16: 16$. OOL : POL : OCL: $17: 7: 10$. Width : length (longitudinal measure) of the postocellar area: $9: 5$. Longest diameter of eye : length of 3rd antennal segment: $21: 22$. Ratios of hind tarsal segments $1-5$ without claw: $52: 16: 15: 8: 18$. Length of gena : diameter of anterior ocellus: 5 : 4. Depth of clypeal emargination : median length of clypeus: $12: 24$. Length of hind tibia : length of ovipositor: $65: 28$. LID :IDMO: EL: $36: 45: 43$. ICD : ITD = $17: 46$. IATS : MB : OATS: $28: 52: 21$. Antenna long and slender, about as long as head, thorax and first 2 abdominal segments (including propodeum) combined.

Mesoscutellar lobes densely, minutely and deeply punctured, interspaces between punctures densely granulated, matt. Mesoscutellum and mesoscutellar appendage deeply, moderately roughly punctured with moderately large punctures, hardly shiny.

Mesopleuron and mesepisternum very roughly, very deeply punctured with large punctures hardly shiny. Katepimeron and mesopleuron densely, moderately shallowly punctured with dense, moderately large punctures, hardly shiny, Posterior part of metapleuron with sporadic shallow punctures and shallow wrinkles, moderately shiny. First tergite with shallow coriaceous surface sculpture, moderately shiny. Other tergites with dense shallow transverse wrinkles, hardly shiny. 


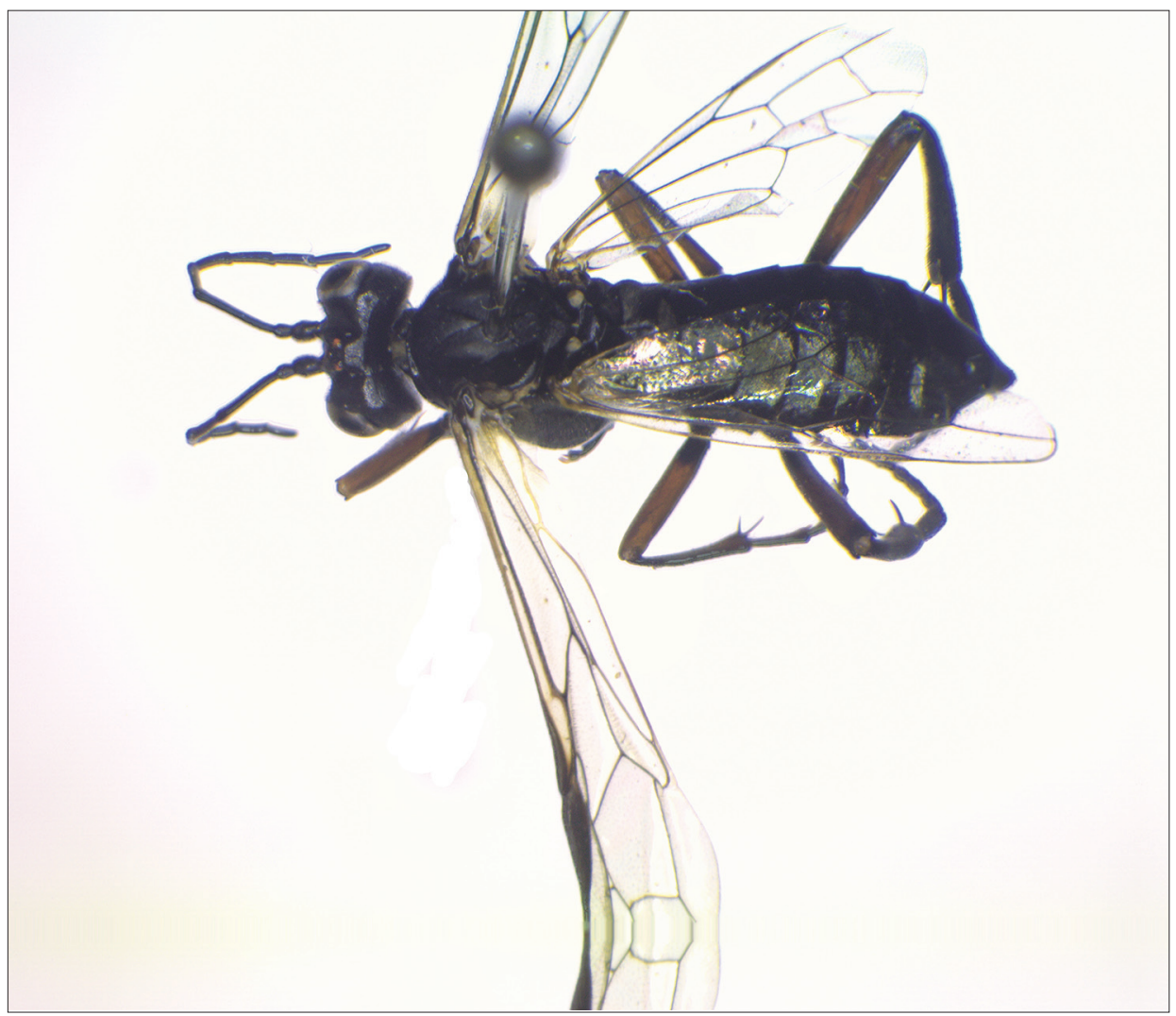

Fig. 1: Tenthredo indonitidula spec. nov. holotype (photo: Haris)

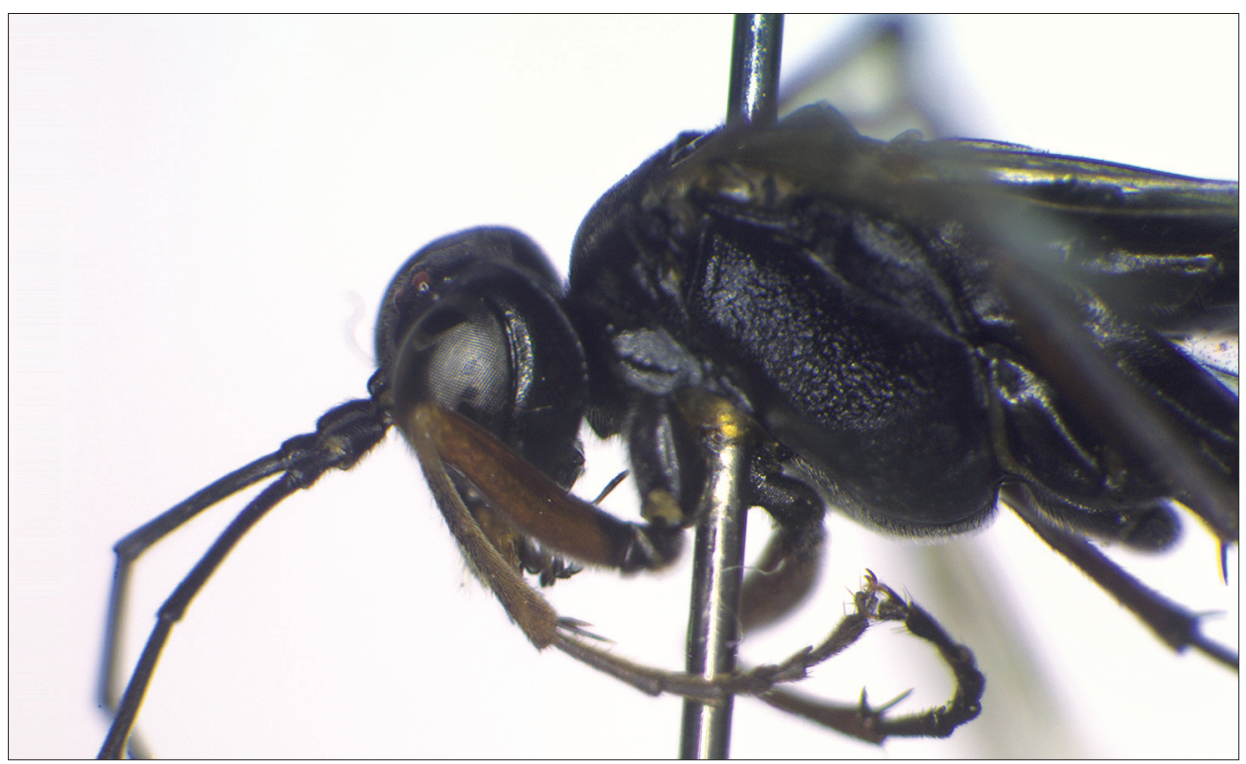

Fig. 2: Head and thorax of Tenthredo indonitidula spec. nov. in lateral view (photo: Haris) 
Mesosternum without spine. Mesoscutellum strongly, pyramidally but bluntly elevated. Mesopleuron strongly but bluntly elevated. Subapical tooth of claw sligthly but clearly shorter and thicker than apical. Last abdominal tergite elongated, covering apex of sawsheath. Length: $10.4 \mathrm{~mm}$.

In ENSLIN (1920), it runs to Tenthredo (Tenthredella) atra Linné, 1758. However, the new species has strongly elevated subpiramidal mesoscutellum and also strongly elevated mesopleuron. These parts are flat in T. atra Linné, 1758. The new species has mesepisternum with very dense punctures which are absolutely rough and deep, crater like. In T. atra, mesopleuron is roughly punctured, but without crater like sculpture. $T$. atra Linné, 1758 is very variable in colour.

The new species also resembles to Tenthredo yinae Wei, 1999, which is larger, 14.5 $\mathrm{mm}$. Round spot on clypeus, mesepisternum, lateral spots and hind margin of propodeum are white (these parts are black in the new species). Colour of legs are also different: hind tibia brownish black, otherwise legs are dominantly black with dark yellowish brown color, not red as in the new species. Mesonotum is shiny and sparsely punctured in $T$. yinae, but in the new species mesonotum is matt, densely and finely punctured, additionally granulated.

In Malaise (1945), the new species runs to Tenthredo kumaonensis (Rohwer, 1921), now Tenthredo dorsivittata (Cameron, 1902). Besides the colour differences: legs are black and white and body is richly decorated with white spots; the new species has black body without white spots and legs are red and black, Tenthredo dorsivittata has sparsely punctured mesoscutellum and shiny and sporadically punctured upper part of mesopleuron. These parts in the new species are dull and deeply and roughly punctured as they are described above.

In SAINI (2007), the new species would run to Tenthredo micropunctata Saini and Vasu, 2001. In the new species, head, thorax and abdomen black, legs coloured with red as it is described above; in Tenthredo micropunctata, body is richly coloured with white and legs without red colour. Clypeus rectangularly incised in Tenthredo micropunctata but it is roundly incised in the new species.

The specific name indonitidula means: indo: from India, nitidula: elegant.

\section{References}

EnsLin, E. 1920: Die Blattwespengattung Tenthredo L. (Tenthredella Rohwer). - Abhandlungen der Zoologisch-Botanischen Gesellschaft in Österreich, Wien 11(1): 1-96.

Haris, A. \& Roller, L. 1998: Three new Tenthredo species from Yunan (Hymenoptera: Tenthredinidae). Folia Entomologica Hungarica, Budapest 59: 135-140.

Haris, A. \& Roller, L. 2007: Sawflies from Laos (Hymenoptera: Tenthredinidae). - Natura Somogyiensis 10: 173-190.

Haris, A. \& SAInI, S. M.. 2018: Tenthredo (Linné, 1758) species from Chopta, India (Hymenoptera: Symphyta: Tenthredinidae). - Natura Somogyiensis 31: 77-88.

NIE, H. \& WeI, M. 1998: Fourteen new species of Tenthredo from Funiushan (Hymenoptera: Tenthredinidae). - : pp. 176-187. In: SHEN, X. \& SHI, Z. (eds.): Insects of the Funiu Mountains Region (1). (The Fauna and Taxonomy of Insects in Henan Vol. 2). - China Agricultural Science and Technology Press, Beijing: 368 pp.

SAINI, M. S. 2007: Genus Tenthredo Linnaeus (Hymenoptera, Symphyta: Tenthredinidae). In: Indian Sawflies Biodiversity. Keys, Catalogue \& Illustrations. - Bishen Singh Mahendra Pal Singh, Dehra Dun 1: [1-7], 1-249. 
WeI, M. \& NIE, H. 1998: Sixteen new species of the genus Tenthredo from Funiushan (Hymenoptera: Tenthredinidae). (In English, abstract in Chinese). - pp. 188-200. In: SHEN, X. \& SHI, Z. (eds.): Insects of the Funiu Mountains Region (1). (The Fauna and Taxonomy of Insects in Henan Vol. 2). - China Agricultural Science and Technology Press, Beijing: 368 pp.

Wei, M., Wen, J. \& Deng, T. 1999: Nine new sawflies from Mt. Jigong (Hymenoptera: Tenthredinidae, Argidae). (In Chinese, abstract in English). - The Fauna and Taxonomy of Insects in Henan, China Agricultural Science and Technology Press 3: 21-32.

WeI, M. \& NiE, H. 2002: Six new species of the genus Tenthredo L. (Hymenoptera: Tenthredinidae) from Henan province. (In Chinese, abstract in English). - : pp. 154-162. In: SHEN, X. \& ZhaO, Y. (eds), Insects of the mountains Taihang and Tongbai regions. (The Fauna and Taxonomy of Insects in Henan, Vol. 5[2003]), China Agricultural Science and Technology Press.

Wei, M. \& Zhong, Y. 2002: Nine new species of Tenthredo from Henan province (Hymenoptera: Tenthredinidae). (In Chinese, abstract in English). - pp. 240-252. In: SHEN, X. \& ZHAO, Y. (eds), Insects of the mountains Taihang and Tongbai regions. (The Fauna and Taxonomy of Insects in Henan, Vol. 5[2003]), China Agricultural Science and Technology Press.

Zhelochovtsev, A. N. 1988: Otryad Hymenoptera - Pereponchatokrylye, Podotryad Symphyta Sidyachebryukhie, pp. 7-234. In: Medvedev, K. H. (ed.) Opredelitel nasekomykh evropeiskoi chasti SSSR, Vol. 3 Hymenoptera, Part 6, Nauka, Leningrad. 
